\title{
G131013
}

\section{ウォータドライブステージの速度制御系設計 （第四報：速度制御に及ぼす負荷の影響）}

\begin{abstract}
Design of speed control system of water driven stage
\end{abstract} \\ $\left(4^{\text {th }}\right.$ report: Influence of load on speed control system) \\ Yusuke TORII $^{* 1}$,Toshiaki SANO ${ }^{* 1}$, Yohichi NAKAO ${ }^{* 2}$ and Kenji SUZUKI ${ }^{* 2}$ \\ ${ }^{* 1}$ Graduate school of Kanagawa Univ. Dept. of Mechanical Engineering \\ Rokkakubashi 3-27-1, Kanagawa-ku, Yokohama-shi, Kanagawa, 221-8686 Japan \\ ${ }^{*}$ Kanagawa Univ. Dept. of Mechanical Engineering \\ Rokkakubashi 3-27-1, Kanagawa-ku, Yokohama-shi, Kanagawa, 221-8686 Japan
}

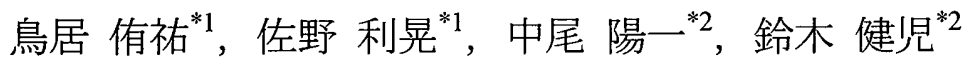

\begin{abstract}
A water driven stage, which is composed of water hydrostatic bearings and the water hydraulic piston mechanism, was developed for liner stage for ultra-precision machine tool, especially, for machining small parts in size. Speed of the water driven stage can be controlled by the supplied water flow rate into the piston-cylinder by use of electromagnetic proportional flow control valve. The purpose of this study is to control the speed of feed motion of the table. In this paper, influence of step load changing on the table of the stage is evaluated by experiments and simulations. It is then verified that the designed feedback control system effectively reduces the influence of the external load acting on the table.
\end{abstract}

Key Words : Water driven stage, Speed control, Ultra-precision machining, Hydrostatic bearing, Water hydraulics

\section{1. 緒言}

超精密加工は，高品位な面粗さ，高い形状精度を実現する手段として，各種レンズ用金型などの需要拡大にも 伴って大きく発展し, これらの加工を安定した精度で可能にすることを目的に研究開発が行われている ${ }^{(1)}$. 超精 密工作機械用のスピンドルや直動テーブルは，工作機械の運動精度を決定し，その結果として，母性原理によっ て被削物の加工精度を決定するため, スピンドルや直動テーブルの高い運動精度が必要不可欠である. そのため 超精密工作機械の案内要素には，多くの場合，案内面を非接触で支持することが可能な静圧軸受が利用されてい る. 例えば，これまでに小型部品の超精密加工への応用を目指して，水静圧案内と水圧駆動機構が組み込まれた ウォータドライブステージが開発された. このステージは駆動流体に水を採用しているため, 粘性摩擦による発 熱の低減，非圧縮性流体であるため高い支持剛性を得られるなどの利点がある.

ダイヤモンドバイトによる鏡面加工に本ステージを利用する際，加工面品位に影響する送り量を一定に保つこ とは，良好な加工面を創成するために重要である．本ステージは水压によりテーブルを駆動させるが，ボールね ビやリニアモータに代表される工作機械の一般的な駆動方式と同様に，切削抵抗等の負荷変動によるテーブルの 速度変動は避けられない, そのため, 送り量を決定するステージの $1 \mathrm{~mm} / \mathrm{s}$ 以下での速度制御が必要不可欠であ る.

本ステージはピストン室への水の供給流量によって, テーブル速度を制御できる. これまでの研究で, 本ステ 一ジに比例弁を用いて $1 \mathrm{~mm} / \mathrm{s}$ 以下で速度制御が可能であることを明らかにし(2), 本ステージと比例弁の特性 ${ }^{(3)}$ を実験により求めた。 そこで，比例・積分型のフィードバック制御系の設計(4)が行われた.

本報では，設計した速度制御系に対して，切削力等の外部負荷が本ステージの送り速度に与える影響を，実験 とシミュレーションによって検討した.

\footnotetext{
${ }^{* 1}$ 学生員, 神奈川大学大学院（T221-8686 横浜市神奈川区六角橋 3-27-1）

*2 正員, 神奈川大学 工学部（广221-8686 横浜市神奈川区六角橋 3-27-1）

E-mail: nakao@kanagawa-u.ac.jp
}

[No.13-1］ 日本機械学会 2013 年度年次大会講演論文集 [2013.9.8-11, 岡山] 


\section{2. ウォータドライブステージの構造と特徵}

ウォータドライブステージのテーブルは，ステージに組み込まれた長方形断面を有する水圧シリンダによって 駆動される. ウォータドライブステージの基本構造を図 1 に示す. 本ステージは, ステージ本体に設けられた水 静圧軸受により，テーブルを非接触で支持する．シリンダ室への供給・排出用の流路及び，各水静圧軸受への供 給・排出用の流路はステージ本体の内部に設けられており，これらの流路を通して水静圧軸受部とステージの左 右 1 つずつあるシリンダ室に水が供給される. その結果, 他方のシリンダ室との間に差圧が生じ, 水静圧軸受で 支持されたテーブルが直線運動する. ウォータドライブステージは，上下左右対称構造になっている. さらにそ の中心には長方形断面のピストン機構が形成されており，ピストンに発生した駆動力がテーブル重心に作用する 構造となっている。このため, ピッチング・ヨーイングの発生を抑制し, 高精度な直線運動を創成することが可 能である.

図 2 に制御の駆動のための流体回路図を示す：シリンダ室に水を供給するときは比例制御弁（以下，比例弁） を介して供給する．供給流量は比例弁への入力電圧を制御することにより行うことができ，その結果テーブルの 速度を制御することが可能である。

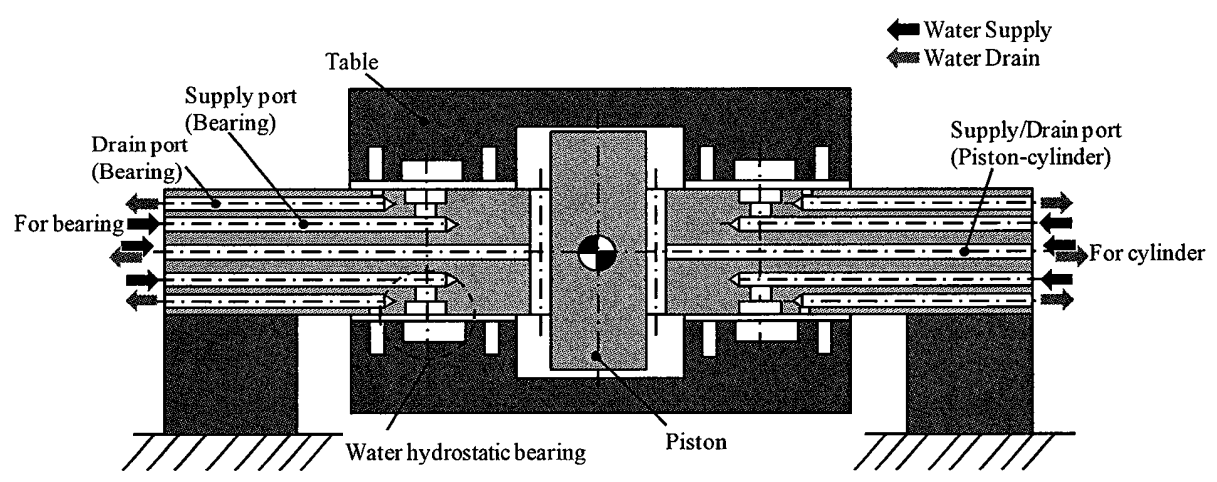

Fig. 1 Structure of water driven stage

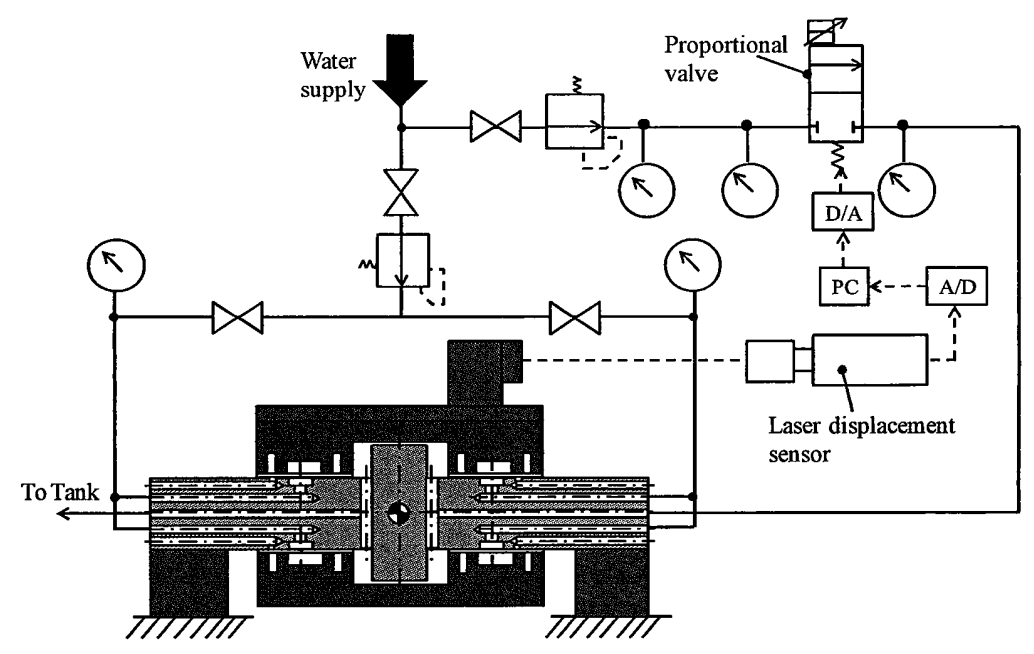

Fig. 2 Control system of water driven stage

\section{3. ステージの運動方程式とフィードバック制御系}

ウォータドライブステージの速度制御系を示す．まず，ステージの運動方程式を示すと，ステージの左右シリ ンダ室の差圧を $p_{t}$, 質量 $M$, テーブル速度 $v$ とすると, ウォータドライブステージの運動方程式は式(1)で表さ れる.

$$
M \frac{d v}{d t}=A p_{t}-c v-F_{c}
$$


ここで, $F_{c}$ : 外部負荷, $c$ : テーブルとステージ間の水による粘性抵抗である. また, 連続の式より式(2)が得 られる。

$q-\frac{1}{R} p_{t}=A v$

ここで, $q$ : シリンダ室への供給流量, $R$ : ピストン・シリンダ間の隙間における流れの抵抗である.

次にステージの水圧シリンダに供給する水の流量制御に用いた，比例弁の圧力流量特性を，式(3)に表す.

$q=k_{1} u-k_{2} p_{v}$

ここで, $u$ : 比例弁への制御電圧, $p_{v}$ : 比例弁下流側の圧力, $k_{1}, k_{2}$ : 比例弁のゲインである. また, 比例弁か らステージまでの管路中を流れる流体の運動方程式は, 水の密度を $\rho$, 流路長さ $l$, 流路断面積 $A_{f}$ とすると式

(4)で表わされる.

$$
\frac{\rho l}{A_{f}} \frac{d q}{d t}=p_{v}-p_{t}
$$

このとき, 式(1)から式(4)までをラプラス変換し, 流量制御弁への制御電圧 $u$ に対する, ステージ速度間の伝 達関数を求めると式(5)になる.

$$
\hat{v}=\frac{\frac{1}{A+\alpha}}{1+2 \frac{\zeta}{\omega_{n}} s+\frac{s^{2}}{\omega_{n}^{2}}}\left\{k_{1} u-\frac{\alpha}{c}\left(1+s T_{2}\right) F_{c}\right\}
$$

ここで, $T_{2}=\frac{k_{2} \rho l}{A_{f}\left(1+k_{2} R\right)}, \quad \alpha=\frac{c\left(1+k_{2} R\right)}{A R}$ であり, $T_{2}$ は時定数である.

式(5)より制御対象のブロック線図を図 3 に示す.ここで， $F_{c}$ は切削抵抗などの外部負荷であり，式(5)におい て制御電圧 $u=0$ としたとき $F_{\mathrm{c}}$ と $v$ 間の関係を考えると, オープンループ制御系では外部負荷の変動がテーブル の速度に影響し，定常誤差が発生する．そこで, 外部負荷の変動による定常誤差を低減することが可能な比例・ 積分型フィードバック制御系を構成することにした. 制御系のブロック線図を, 図 4 に示す. ここで, $v_{\mathrm{d}}$ は速度 目標値である.

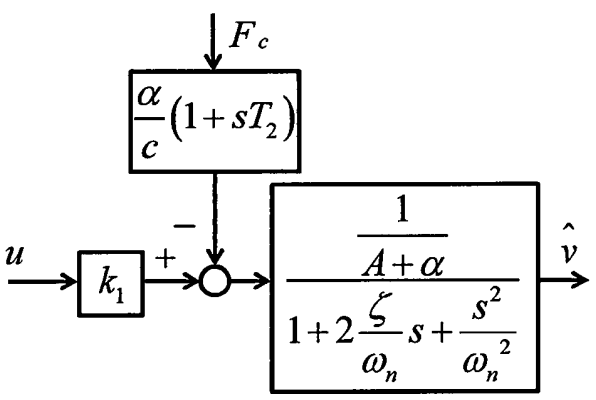

Fig. 3 Open loop control system

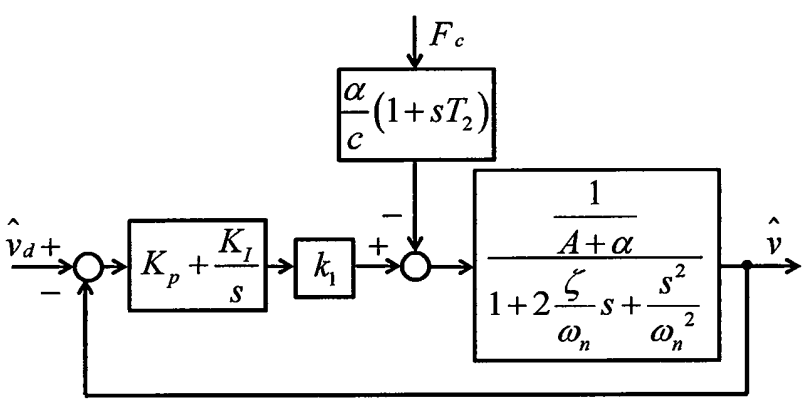

Fig. 4 Designed feedback control system

図中， $K_{P}$ と $K_{I}$ は定めるべき比例ゲインと積分ゲインである.

図 4 のように設計されたフィードバック制御系に対して, $F_{c}=0$ とした場合, $v_{d}$ と $v$ 間の伝達関数は, 次式で表わ される。

$$
G(s)=\frac{1+\kappa s}{1+\frac{\kappa}{k_{1} K_{p} K_{s}}\left(1+k_{1} K_{p} K_{s}\right) s+\frac{2 \kappa \zeta}{k_{1} K_{p} K_{s}} \frac{s^{2}}{\omega_{n}^{2}}+\frac{\kappa}{k_{1} K_{p} K_{s}} \frac{s^{3}}{\omega_{n}^{2}}}
$$

同様にして, $v_{d}=0$ とした場合， $F_{\mathrm{c}}$ と $v$ 間の伝達関数は，次式で表わされる. 
$G_{f}(s)=\frac{\alpha \kappa}{c k_{1} K_{p}} \frac{\left(1+s T_{2}\right) s}{1+\frac{\kappa}{k_{1} K_{p} K_{s}}\left(1+k_{1} K_{p} K_{s}\right) s+\frac{2 \zeta}{k_{1} K_{p} K_{s} \omega_{n}} s^{2}+\frac{s^{3}}{k_{1} K_{p} K_{s} \omega_{n}{ }^{2}}}$

式(6), 式(7)において， $\kappa=\frac{K_{p}}{K_{I}}, K_{s}=\frac{1}{A+\alpha}$ であり， $K_{S}$ は供給流量とテーブル速度閒のゲインである.

\section{4. フィードパック制御系の基本性能}

設計されたフィードバック制御系の基本性能を，実験とシミュレーションによって調べた. 図 5(a)に静特性， 図 5(b)にステップ応答をそれぞれ示す. ステージの運転条件として, 比例弁への供給圧力は $0.2 \mathrm{MPa}$, 静圧軸受 部への供給圧力を $0.4 \mathrm{MPa}$ とし，比例ゲイン $K_{P}$ を $9 \times 10^{4} \mathrm{Vs} / \mathrm{m} ，$ 積分ゲイン $K_{I}$ を $6.5 \times 10^{5} \mathrm{~V} / \mathrm{m}$ とした.

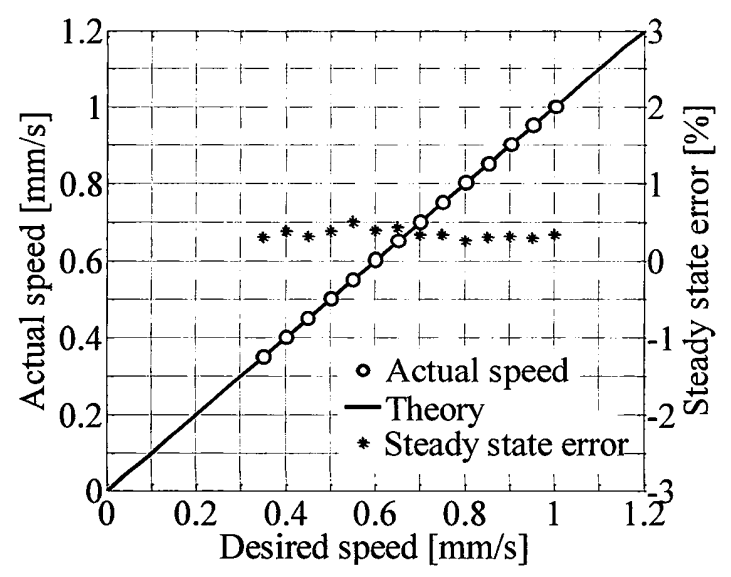

(a) Static characteristic

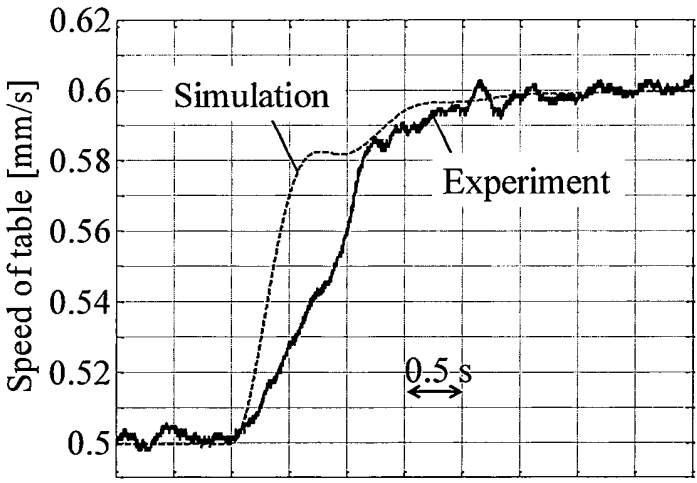

Time $[\mathrm{s}]$

(b) Step response $(0.5 \mathrm{~mm} / \mathrm{s}$ to $0.6 \mathrm{~mm} / \mathrm{s})$

Fig. 5 Performance of PI control system

図 5(a)より，目標速度と実際のテーブル速度は良く一致しており，定常偏差は，約 $0.5 \%$ 以下であった．図 5(b) よりステップ応答でオーバシュートは見られず，立ち上がり時間は，約 $1.25 \mathrm{~s}$ であった．一方，シミュレーショ ン結果と比較すると，実験におけるテーブル速度は，立ち上がりに遅れが観察された.

\section{5. 速度制御に及ぼす負荷の影䇾}

設計した速度制御系に及ぼす負荷の影響を，オープンループ制御系を用いた場合と，フィードバック制御系を 用いた場合のそれぞれについて調べた．実験では，比例弁への供給圧力は $0.2 \mathrm{MPa}$ ，静圧軸受への供給圧力は 0.4 $\mathrm{MPa}$ とし， $K_{P}$ を $9 \times 10^{4} \mathrm{Vs} / \mathrm{m}, K_{I}$ を $6.5 \times 10^{5} \mathrm{~V} / \mathrm{m}$ とした. テーブルに作用する外部負荷変動は，超精密加工で生 じる $0.1 \mathrm{~N}$ 程度の切削抵抗を想定したステップ状に変化する負荷変動をテーブルに作用させた. 実験結果を図 6 と図 7 にそれぞれ示した。一方，オープンループ制御系による実験においては，図 6(a)，(b)に示すように，負荷 の変動後, $0.012 \mathrm{~mm} / \mathrm{s}$ 程度の定常誤差が発生した.一方, フィードバック制御系を用いた同様の実験では, 図 7(a), (b)に示すように定常誤差は十分に小さくなり, 整定時間は約 $1.25 \mathrm{~s}$ でシミュレーションともよく一致している. なお，各実験結果に共通して，9 Hz 程度の振動が観察された. これは静圧軸受部のドレイン回路に用いているポ ンプの振動が影響していると考えられる。 


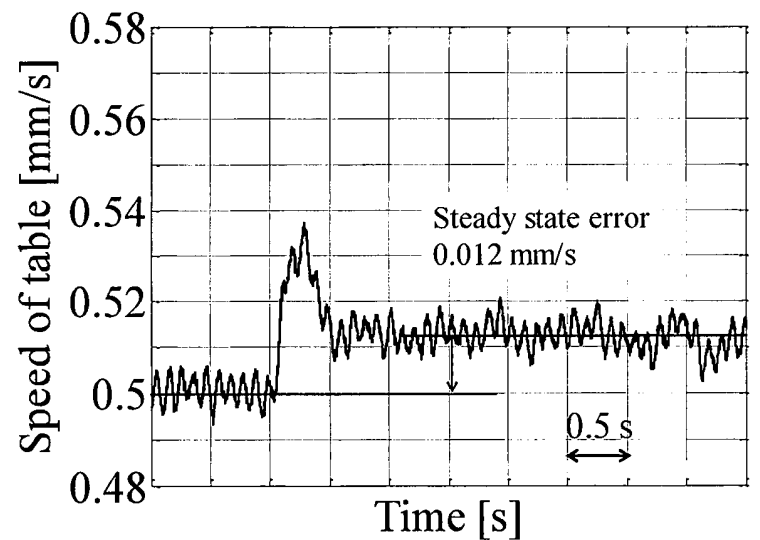

(a) Lord increase

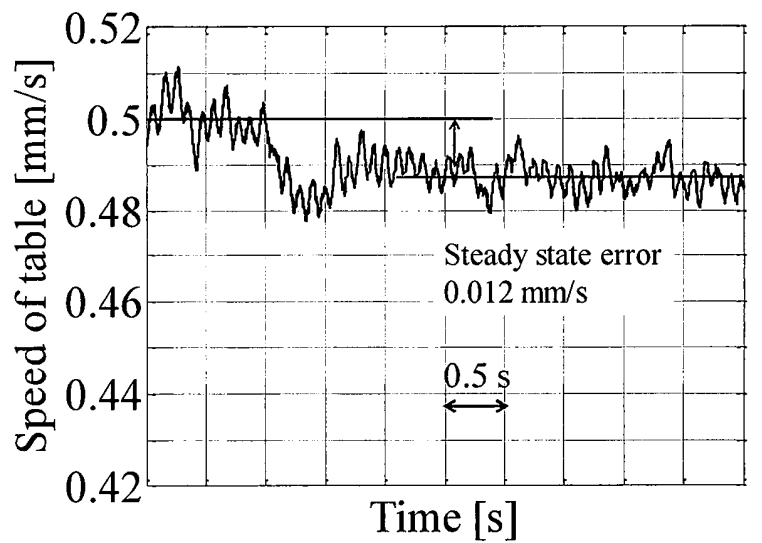

(b) Load decrease

Fig. 6 Step response of open loop control system

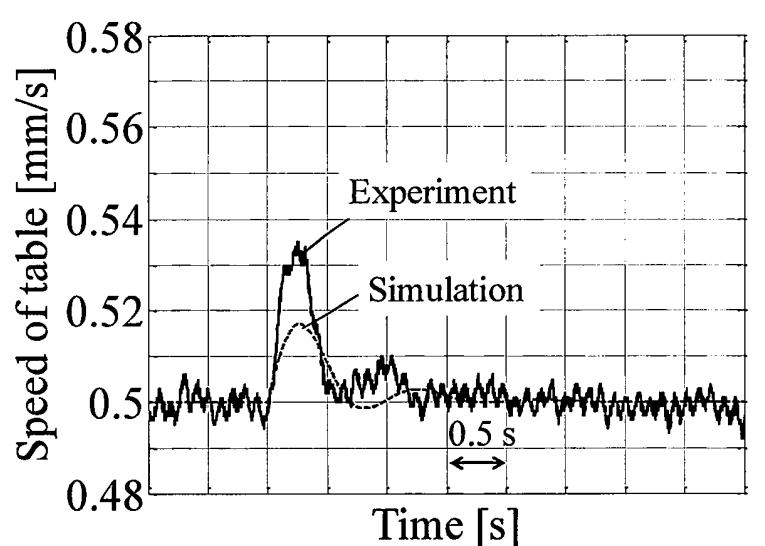

(a) Lord increase

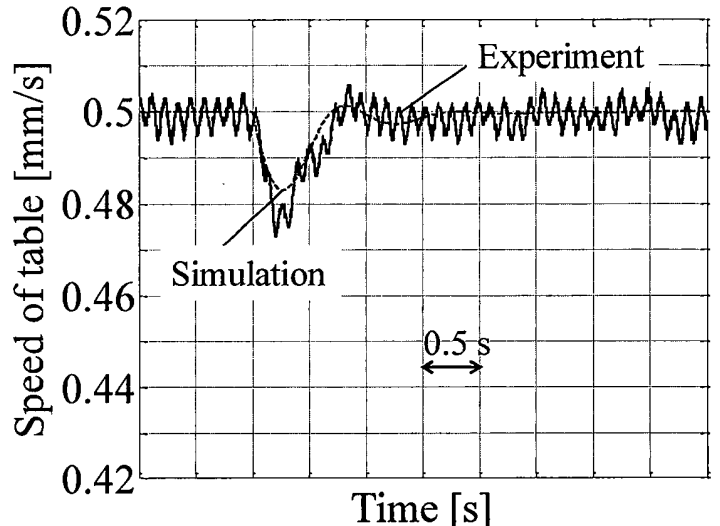

(b) Load decrease

Fig. 7 Step response of designed feedback control system

\section{6. 結言}

本研究では，ウォータドライブステージの送りを一定にすることを目的に，速度制御系の設計を行い，これま でに設計された速度制御系の基本性能に加えテーブルに作用する外部負荷の影響をシミュレーションと実験によ って調べた. その結果, 静特性は, 定常偏差において約 0.5 \%以下で, 動特性としてステップ応答を測定した結 果, 立ち上がり時間は約 $1.25 \mathrm{~s}$ であった. オープンループ制御系とフィードバック制御系を比較した結果，オー プンループ制御系で観察された定常誤差は，フィードバック制御系を用いることで十分小さくなり，整定時間は 約 $1.25 \mathrm{~s}$ でシミュレーションともよく一致する結果を得た. 今後は, 各実験で発生している $9 \mathrm{~Hz}$ 程度の振動の原 因とその低減を目指し，速度制御に影響を及ぼす外乱の低減を目指寸必要がある. また，制御系の立ち上がり時 間や整定時間に関して, 応答性がより向上する制御ゲインの選定, 及び制御システムの構築を行う必要がある.

\section{文献}

（1）田中克敏, 超精密加工技術の現状と展望, 生産加工・工作機械部門講演会:生産と加工に関する学術講演会, No.3, pp.1-6, (2001)

（2）佐野, 鈴木，中尾，ウォータドライブステージの速度制御系設計 第一報 : ウォータドライブステージのモデル化， 日本機械学会 2012 年度年次大会講演論文集, (2012), G130014.pdf.

（3）佐野，鈴木，中尾，ウォータドライブステージの速度制御系設計 第二報: 比例弁による速度制御の試み, 日本機械 学会第 9 回生産加工・工作機械部門講演会, (2012), 37-38.

(4) 佐野, 鳥居, 鈴木, 中尾, ウォータドライブステージの速度制御系設計 第三報 : ステージのフィードバック制御 系の性能評価, 日本機械学会第 19 期総会講演会講演論文集, (2013), 183-184. 